\title{
Uji Aktivitas Antibakteri Sediaan Hand Sanitizer Yang Di Produksi Secara Lokal Terhadap Bakteri Staphylococcus Aureus
}

\author{
Asri Wido Mukti ${ }^{l}$ \\ ${ }^{1}$ Program Studi Farmasi, FakultasIlmu Kesehatan, Universitas PGRI Adi Buana, Surabaya, Indonesia
}

\section{INFO ARTIKEL \\ Sejarah artikel: \\ Penerimaan naskah: 28 Januari 2021 \\ Penerimaan naskah revisi: 26 Februari 2021 \\ Disetujui untuk dipublikasikan: 31 Mei 2021}

\section{Kata kunci : \\ Aktivitas \\ Antibakteri, \\ Covid-19, Hand \\ Sanitizer, \\ Staphylococcus \\ Aureus}

\begin{abstract}
A B S T R A K
Meningkatnya status penyakit corona (Covid -19) menjadi pandemik oleh WHO menyebabkan masyarakat menjadi panic buying terhadap beberapa alat kesehatan salah satunya adalah Hand Sanitizer. Beberapa oknum yang mengambil kesempatan untuk mendapatkan keuntungan dengan membuat sendiri Hand Sanitizer yang formulanya dipertanyakan karena tidak memiliki ijin edar dan diperdagangkan sehingga kualitasnya pun menjadi dipertanyakan. Oleh karena itu penelitian ini bertujuan untuk mengetahui aktivitas antibakteri dari Hand Sanitizer yang diproduksi tanpa ijin edar dan diperjual belikan secara bebas di marketplace terhadap bakteri S.aureus. Staphylocccus aureus merupakan jenis bakteri transient yang sering didapati pada tangan, sehingga dalam penenlitian ini digunakan bakteri tersebut. Metode yang digunakan yaitu dengan menggunakan teknik difusi cakramdan ditentukan zona hambatnya. Penelitian ini menggunakan kontrol positif berupa Hand Sanitizer yang telah memiliki ijin edar dan kontrol negatif berupa oil carrier. Dari 5 sampel Hand Sanitizer tersebut yang terdapat zona hambat hanya pada kode sampel HS1 (alkohol 70\% dan castor oil) dan HS5(alkohol 70\%) dengan diameter zona hambat sebesar1,8 $\mathrm{mm} \pm 3,12$ dan 4,3mm \pm 3,72 dimana menunjukkan respon hambatan pertumbuhan pada bakteri S.aureus sangat lemah lemah $(\leq$ $10 \mathrm{~mm}$ ). Kontrol positif (Merek Hand Sanitizer yang berijn edar) pada penelitian ini juga menunjukkan respon hambatan pertumbuhan bakteri S.aureus yang sangat lemah $(7,1 \mathrm{~mm} \pm 1,21)$. Hal ini menunjukkan bahwa mencuci tangan dengan sabun dan air lebih baik daripada menggunakan disinfektan tangan berbahan dasar alkohol dalam menghilangkan virus dari tangan. Dapat disimpulkan bahwa aktivitas antibakteri pada Hand Sanitizer yang diproduksi secara lokal ini sangat lemahdalam menghambat bakteri S.aureus.
\end{abstract}

\section{Antibacterial Activity of Hand Sanitizer Produced Locally Against Staphylococcus Aureus Bacteria}

Keywords:

Antibacterial

activity test,

Covid-19, Hand

Sanitizer,

Staphylococcus

Aureus

\begin{abstract}
A B S T R A C T
Pandemic status of corona disease (Covid -19) by WHO has caused people to panic buying for several medical devices, such as Hand Sanitizer. Several individuals took the opportunity to make a profit by making their own Hand Sanitizers whose formula was questionable because they did not have a distribution license and were traded freely so that their quality was questioned. Therefore, this study aims to determine the antibacterial activity of Hand Sanitizers which are produced without distribution permits and are traded freely in the marketplace against S.aureus bacteria. Staphylocccus aureus is a type of transient bacteria that is often found on the hands, so this research uses these bacteria. The method is by using the disc diffusion technique and the zone of inhibition is determined. This study uses a Hand Sanitizer which has a distribution permit as positive control and carrier oil as a negative control. 5 samples of Hand Sanitizer were collected and there are inhibition zones only in the sample code HS1 (70\% alcohol and castor oil) and HS5 (70\% alcohol) with an inhibition zone diameter of $1.8 \mathrm{~mm} \pm 3.12$ and $4.3 \mathrm{~mm} \pm 3,72$ which showed a very weak response to growth inhibition in S.aureus bacteria $(\leqslant 10 \mathrm{~mm}$ ). The positive control (brand of Hand Sanitizer which is licensed) in this study also showed a very weak response to growth inhibition of S.aureus bacteria $(7.1 \mathrm{~mm} \pm 1.21)$. This suggests that washing hands with soap and water is better than using alcohol-based hand disinfectants in removing viruses from hands.
\end{abstract}


= 


\section{Pendahuluan}

Memakai masker dan mencuci tangan sangat penting untuk memperlambat penyebaran SARS CoV-2 ${ }^{1}$. Mencuci tangan yang paling efektif adalah dengan menggunakan sabun dan air mengalir ${ }^{2}$. Namun, seringkali sulit untuk mencuci tangan setiap waktu sehingga penggunaan Hand Sanitizer menjadi solusi yang lebih praktis untuk membersihkan tangan.

Panic buying marak terjadi di kalangan masyarakat dunia, termasuk di Indoneisa sejak meningkatnya statuspandemik yang ditetapkan oleh WHO terhadap penyakit Covid -19.Alat Kesehatan yang menjadi target panic buying ini salah satunya adalah pembersih tangan (Hand Sanitizer).Hand Sanitizer adalah cairan pembunuh mikroba yang efektif, gel atau busa yang digunakan untuk mendisinfeksi dan membersihkan tangan tanpa sabun butuhkan untuk sabun dan air ${ }^{3}$.Panic buying yang dilakukan oleh masyarakat karena kekhawatiran terhadap wabah covid 19 ini menyebabkan sulitnya mendapatkan produk Hand Sanitizer sehingga menyebabkan harga yang melambung tinggi.

Beberapa oknum yang mengambil kesempatan untuk mendapatkan keuntungan dengan membuat sendiri Hand Sanitizer yang formulanya dipertanyakan karena tidak memiliki ijin edar dan diperjual belikan dengan bebas di marketplace sehingga kualitasnya pun menjadi dipertanyakan.

Badan Pengawas Obat dan Makanan (BPOM) sendiri telah memberikan penjelasan mengenai izin produk Hand Sanitizer. Berdasarkan Permken RI no. 62 tahun 2017 tentang ijin edar alat kesehatan bahwa Hand Sanitizer ini termasuk dalam kategori Perbekalan Keshatan Rumah Tangga (PKRT). Produk PKRT yang diproduksi, dan akan diedarkan harus memiliki ijin edar dari Kementrian Kesehatan. Tidak ada larangan untuk masyarakat memproduksi Hand Sanitizer sendiri menurut pedoman WHO, tapi jika ingin diperjual belikan maka harus memiliki izin edar dari kementrian kesehatan ${ }^{4}$.

WHO telah mengeluarkan formula sebagai pedoman untuk pembuatan Hand Sanitizer untuk keperluan kalangan sendiri atau diproduksi secara lokal. Formulasi tersebut jika diproduksi local tidak boleh melebihi dari 50 liter. Hand Sanitizer berbahan dasar alcohol adalah satu-satunya cara yang dikenal untuk secara cepat dan efektif menonaktifkan beragam potensi mikroorganisme berbahaya di tangan ${ }^{5,6}$.

Habitat mikroorganisme di tangan dibagi menjadi flora menetap (resident) dan sementara (transient). Resident flora yang sering terdapat pada tangan adalah Staphylococcus aureus, Staphylococcus epidermidis, dan Enterococcus faecalis yang berkoloni di lapisan kulit yang lebih dalam dan tahan terhadap pengangkatan mekanis. Transient Flora terdiri dari $S$. aureus, Escherichia coli, dan Pseudomonas aeruginosa yang menjajah lapisan superfisial kulit dalam waktu singkat ${ }^{6}$. Oleh karena itu, digunakan S.aureusuntuk menentukan efektivitasnya berbagai Hand Sanitizer yang diproduksi secara lokal dalam penelitian ini.
Flora transient yang terdapat di lapisan kulit yang superfisial dapat dibersihkan dengan cara memperhatikan kebersihan tangan secara rutin. Mikroorganisme ini biasanya tidak berkembang biak di kulit, tetapi mereka bertahan hidup dan secara sporadis berkembang biak di permukaan kulit. Kulit manusia normal umumnya terdapat bakteri, dengan total jumlah bakteri aerob mulai dari lebih dari $1 \times 10^{6}$ pembentukan koloni unit (CFU) $/ \mathrm{cm}^{2}$ di kulit kepala, $5 \times 10^{5} \mathrm{CFU} /$ $\mathrm{cm} 2$ di aksila, dan $4 \times 10^{4} \mathrm{CFU} / \mathrm{cm} 2$ pada perut hingga $1 \times 10^{4} \mathrm{CFU} / \mathrm{cm}^{2}$ di lengan bawah ${ }^{5}$.

Sebagian besar produk Hand Sanitizer yang efektif adalah yang memiliki formulasi berbasis alkohol yang mengandung $62 \%-95 \%$ alkohol karena dapat mengubah sifat protein mikroba dan kemampuan untuk menonaktifkan virus ${ }^{7}$. alcohol berperan penting sebagai bahan aktif untuk membunuh mikroba. Beberapa merek Hand Sanitizer yang diperjual belikan di marketplace didapati ada yang tidak mengandung alkohol yang merupakan komponen utama sebagai antibakteri sehingga efektivitasnya menjadi dipertanyakan.

Bentuk sediaan Hand Sanitizer yang beredar di marketplace pun bermacam-macam seperti gel, liquid, dan spray. Menurut penelitian dari Babeluk yang membandingkan efektivitas dari ketiga bentuk sediaan Hand Sanitizer diatas menyatakan bahwa sediaan spray memiliki angka penurunan bakteri yang paling besar yaitu sekitar 28\% dbandingkan dengan sediaan liquid dan gel $^{8}$. Pada penenlitian ini digunakan sampel berupa Hand Sanitizer spray.

Penelitian ini bertujuan untuk mengevaluasi efek antibakteri dari Hand Sanitizer yang diproduksi secara local dan beredar di marketplace tanpa ijin edar sehingga dapat turut mencegah penularan penyakit covid-19 ini dengan Hand Sanitizer yang terstandar menjadi tercapai.

\section{Metode}

Penlitian ini merupakan penelitian eksperimental yang dilakukan di Laboratorium Professor Nidom Foundation. Lima merek Hand Sanitizer yang berbeda dan tanpa izin edar dipilih berdasarkan popularitas di marketplace. Kontrol positif dan kontrol negatif juga diberikan pada penelitian ini. Hand Sanitizer yang berijin edar digunakan sebagai kontrol positif yang ditujukan untuk memberikan perbandingan hasil dengan sampel Hand Sanitizer yang tidak berijin edar. Hand Sanitizer yang berijin edar sudah dapat dipastikan bahwa proses pembuatan dari aspek formulasi dan keefektifan sudah pasti terjamin mutunya. Sedangkan carrier oil digunakan sebagai kontrol negatif dimana carrier oil tidak memiliki aktivitas antibakteri sehingga tidak memberikan zona hambat pada media agar yang sudah berisi bakteri S.aureus. Komposisi kelimasampel Hand Sanitizer tersebut tercantum pada tabel berikut : 
Tabel 1 Komposisi Hand Sanitizer

Sampel Komposisi

\begin{tabular}{|c|c|}
\hline HS 1 & Alkohol $70 \%$, Castor oil $0,2 \%$ \\
\hline HS 2 & Strong Acid (Kangen water) \\
\hline HS 3 & Alkohol 70\%, Gliserol, $\mathrm{H} 2 \mathrm{O} 2$, Aquadest \\
\hline HS 4 & $\begin{array}{l}\text { Isopropil Alkohol, Aloevera, Lavender Essential } \\
\text { Oil }\end{array}$ \\
\hline HS 5 & Alkohol 70\% \\
\hline Kontrol (+) & Alkohol 70\%, Vitamin E 4\%, Castor oil 0,2\% \\
\hline Kontrol (-) & Avocado oil, rosemary Essential Oil, Aquadest \\
\hline
\end{tabular}

Media kultur yang digunakan dalam penelitian ini adalah Mueller Hinton untuk metode difusi agar sedangkan nutrient broth dan media nutrient agar untuk isolat bakteri. Isolat klinis S. aureus diperoleh dari lempeng kultur dari masing-masing mikroorganisme yang diawetkan pada nutrient slants agar dan disimpan pada suhu $4{ }^{\circ} \mathrm{C}$ di Laboratorium Professor Nidom Foundation Surabaya.

Teknik difusi cakram dijelaskan oleh bauer et al dan Valgas et al. digunakan untuk evaluasi aktivitas antimikroba pembersih tangan ${ }^{9,10}$.

Agar Mueller Hinton steril diinokulasi dengan organisme uji standar yaitu S.aureus[Gambar 1]. Kapas steril dicelupkan ke dalam tabung reaksi yang berisi inokulum dan diputar dengan benar untuk memungkinkan kontak maksimum. Inokulum dibiarkan mengering selama beberapa menit pada suhu kamar dengan penutup tertutup.

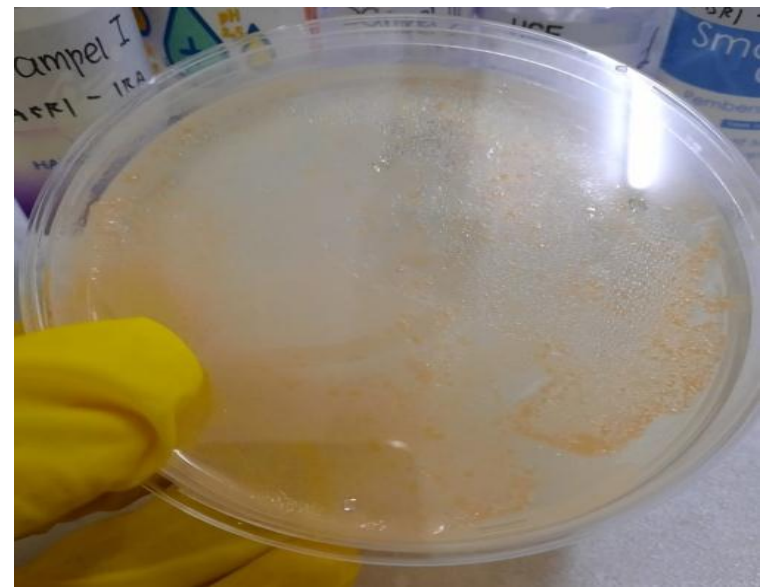

Gambar 1. Media agar Mueller Hinton yang telah di inokulasikan dengan S.aureus

Cakram disc direndam kedalam larutan Hand Sanitizer selama 15 menit kemudian dimasukkan ke media agar yang telah berisi bakteri S.aureus. Kontrol positif yang digunakan adalah Hand Sanitizer yang mempunyai izin edar.Sedangkan kontrol negatif adalah menggunakan carrier oil. Kemudian cawan petri tersebut diinkubasi selama 24 jam pada suhu $37^{\circ} \mathrm{C}$ kemudian diperiksa untuk zona penghambatan yang menunjukkan tingkat kerentanan atau resistensi organisme uji terhadap agen antibakteri. Tes dilakukan replikasi sebanyak tiga kali, dan dihitung rata-rata zona hambat. Zona hambatan diukur dengan bantuan kaliper digital (mm) (Gambar 2).

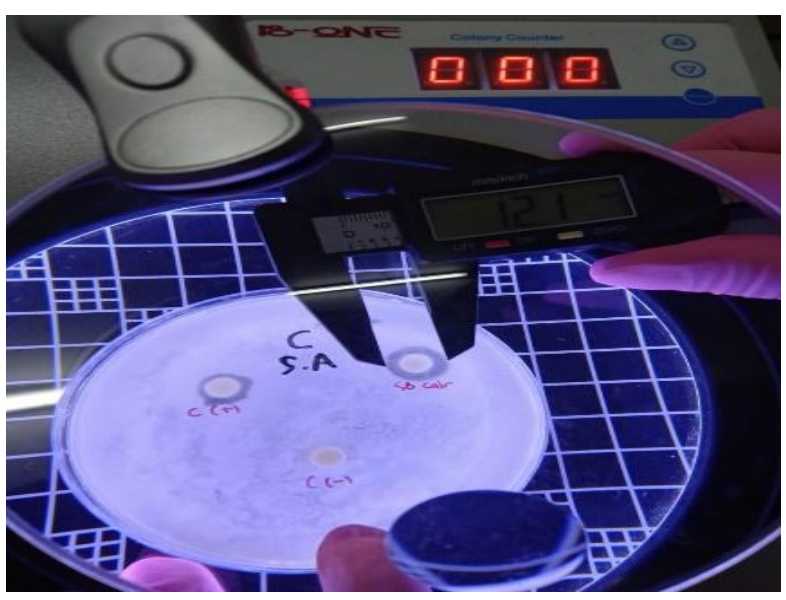

Gambar 2. Pengukuran Zona Hambat

\section{Hasil dan Diskusi}

Hasil pengukuran zona hambat didapatkan hasil bahwa yang terdapat zona hambat adalah HS1, HS5 dan kontrol positif. Sedangkan pada HS2, HS3, HS4, dan kontrol negatif tidak terdapat zona hambat (Tabel 2).

Tabel 2. Diameter Zona Hambat (mm)

\begin{tabular}{lcccc} 
& \multicolumn{4}{c}{ Tabel 2. Diameter Zona Hambat (mm) } \\
\cline { 2 - 4 } Kode HS & \multicolumn{2}{c}{ Replikasi (mm) } & Rata-Rata (mm) \pm SD \\
& $\mathbf{2}$ & $\mathbf{2}$ & $\mathbf{3}$ & \\
\hline HS 1 & 5,4 & 0 & 0 & $1,8 \pm 3,12$ \\
\hline HS 2 & 0 & 0 & 0 & 0 \\
\hline HS 3 & 0 & 0 & 0 & 0 \\
\hline HS 4 & 0 & 0 & 0 & 0 \\
\hline HS 5 & 6,4 & 6,5 & 0 & $4,3 \pm 3,72$ \\
\hline Control (+) & 7,3 & 5,8 & 8,2 & $7,1 \pm 1,21$ \\
\hline Control (-) & 0 & 0 & 0 & 0 \\
\hline
\end{tabular}

Komposisi HS5 mengandung alkohol $70 \%$. Alkohol merupakan bahan aktif utama dalam pembersih tangan berbasis alkohol yang menggunakan aktivitas antimikroba dengan menyebabkan denaturasi protein, melarutkan lemak, mengganggu dengan metabolisme dan lisis sel mereka. Konsentrasi alkohol antara $60-95 \%$ efektif terhadap sebagian besar bakteri dan jamur, dan banyak virus ${ }^{3}$.

Komposisi HS1 sedikit berbeda dengan HS5 yaitu terdapat tambahan castor oil pada komposisinya.Castor oil atau minyak jarak didapat dari tanaman Ricinus communis, dimana telah terbukti mempunyai efek analgesik, antihistamin, antioksidan dan anti-inflamasi ${ }^{10}$. Penelitian lain juga menyebutkan bahwa komposisi castor oil dan klorheksidin 2\% mampu menghambat S.aureus ${ }^{12}$.

Selain HS1 dan HS5 jika dilihat dari komposisinya, HS3 juga seharusnya mempunyai aktivitas antibakteri yang cukup tinggi karena selain mengandung alcohol juga mendandugn hydrogen peroksida yang 
mempunyai aktivitas antibakteri. WHO juga telah menyebutkan bahwa hydrogen peroksida dengan pemberian paparan konsentrasi $1 \%$ selama dua menit pada hans sanitizer dapat menghambat virus SARS$\mathrm{COV}^{13}$. Kemungkinan pada sampel HS ini konsentrasi komposisinya tidak sesuai yang dipersyaratkan sehingga tidak muncul aktvitas antibakteri.

Produk Strong acidic water atau yang biasa dikenal dengan kangen water banyak beredar di masyarakat dan digunakan sebagai hand sanitizer. Produk tersebut disebut-sebut memiliki efektivitas antibakteri. Strong acid yang dipakai disini sangat beragam variasinya, yang digunakan sebagai komposisi pada sampel hand sanitizer dalam penelitian ini adalah air dengan $\mathrm{pH}$ 2,5. Penelitian dari Zaidah et al, memunjukkan bahwa strong acidic water (air $\mathrm{pH} 2,5$ ) tidak memiliki efektivitas antibakteri ${ }^{14}$.Dari guideline CDC disebutkan bahwa strong acid sebagai disinfektan adalah Peracetic acid yang memiliki pH 2,8. Peracetic acid memiliki kemampuan untuk deaktivasi berbagai mikroorganisme patogen termasuk virus dan spora. Tetapi penggunaannya adalah sebatas dalam disinfeksi bidang industri dan peralatan medis dan belum menemukan penjelasan atau bukti aman dalam penggunaannya sebagai hand sanitizer ${ }^{15}$.

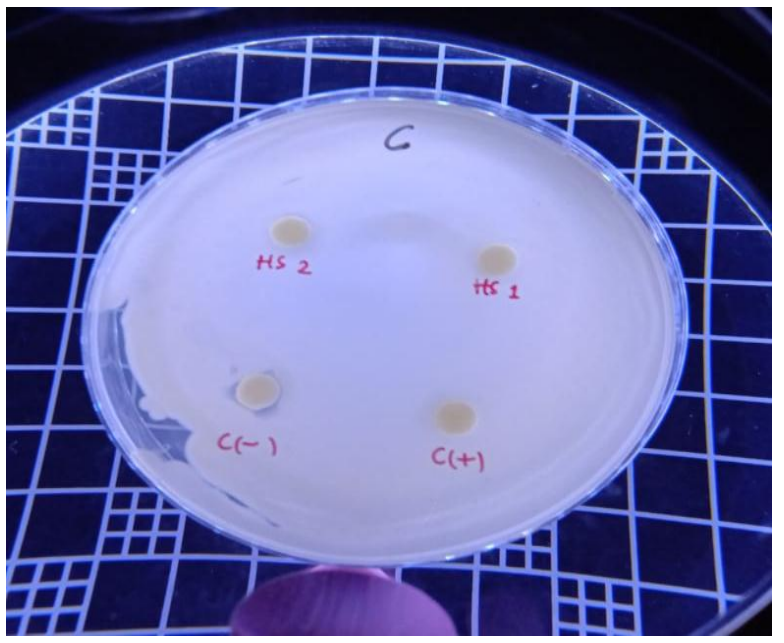

Gambar 3. Zona Hambat HS1 dan HS2

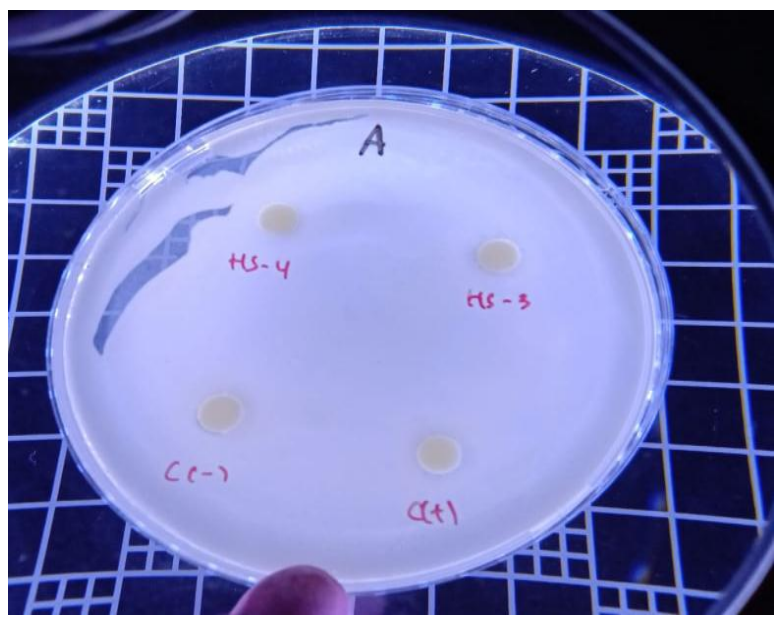

Gambar 4. Zona Hambat HS3 dan HS4

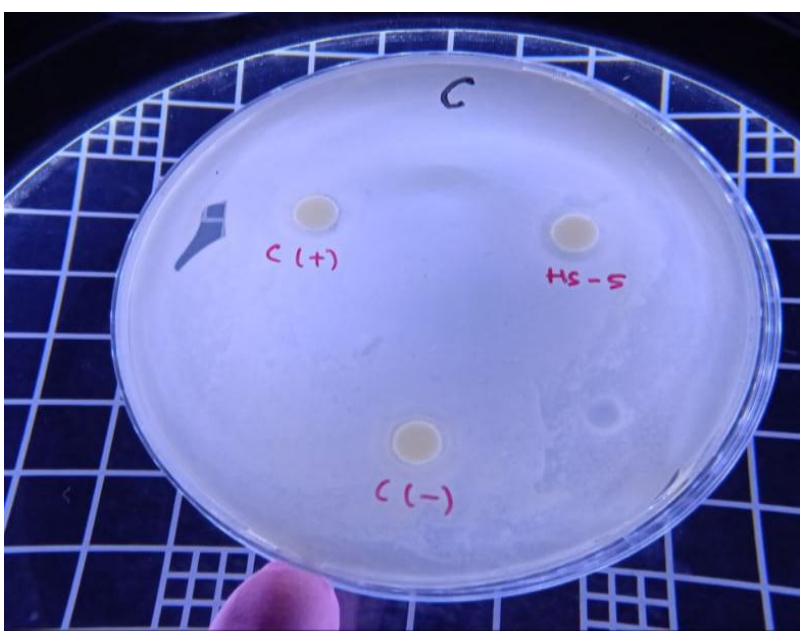

Gambar 5. Zona Hambat HS5

Greenwood mengklasifikasikan rata-rata zona being terhadap respon hambatan pertumbuhan (Tabel 3)

\begin{tabular}{|c|c|}
\hline $\begin{array}{l}\text { Rata-rata Diameter } \\
\text { Zona Bening }\end{array}$ & Respon Hambatan Pertumbuhan \\
\hline$>20 \mathrm{~mm}$ & Kuat \\
\hline $16-20 \mathrm{~mm}$ & Sedang \\
\hline $10-15 \mathrm{~mm}$ & Lemah \\
\hline$\leq 10 \mathrm{~mm}$ & Sangat Lemah \\
\hline
\end{tabular}

Jika dilihat dr tabel tersebut maka zona hambat pada hasil penenlitian ini menunjukkan respn hambatan pertumbuhan bakteri S.aureus yang sangat lemah $(\leqslant 10$ $\mathrm{mm})$. Hal ini menunjukkan bahwa pentingnya untuk selektif membeli Hand Sanitizer yang berijin edar untuk menjamin efektivitasnya.

Kontrol positif (Merek Hand Sanitizer yang berijn edar) pada penelitian ini juga menunjukkan respon hambatan pertumbuhan bakteri S.aureus yang sangat lemah. Hal ini menunjukkan bahwa mencuci tangan dengan sabun dan air lebih baik daripada menggunakan disinfektan tangan berbahan dasar alkohol dalam menghilangkan virus dari tangan ${ }^{17}$.

\section{Daftar Pustaka}

1. Ma, Q. X., Shan, H., Zhang, H. L., Li, G. M., Yang, R. M., \& Chen, J. M. (2020). Potential utilities of mask - wearing and instant hand hygiene for fighting SARS - CoV - 2. Journal of medical virology, 92(9), 1567-1571.

2. Burton, M., Cobb, E., Donachie, P., Judah, G., Curtis, V., \& Schmidt, W. P. (2011). The effect of handwashing with water or soap on bacterial contamination of hands. International journal of environmental research and public health, 8(1), 97104.

3. Chadwick, S., Neskoski, M., Spindler, X., Lennard, C., \& Roux, C. (2017). Effect of hand sanitizer on the performance of fingermark 
detection techniques. Forensic science international, 273, 153-160.

4. Kementerian Kesehatan Republik Indonesia. Pedoman Bimbingan Teknis Perizinan Perbekalan Keshatan Rumah Tangga. Jakarta : Kementerian Kesehatan Republik Indonesia, 2018.

5. WHO, 2009. WHO Guidelines on Hand Hygiene in Health Care.

6. Widmer, A. F. (2000). Replace hand washing with use of a waterless alcohol hand rub?. Clinical infectious diseases, 31(1), 136-143.

7. Jing, J. L. J., Pei Yi, T., Bose, R. J., McCarthy, J. R., Tharmalingam, N., \& Madheswaran, T. (2020). Hand sanitizers: a review on formulation aspects, adverse effects, and regulations. International journal of environmental research and public health, 17(9), 3326.

8. Babeluk, R., Jutz, S., Mertlitz, S., Matiasek, J., \& Klaus, C. (2014). Hand hygiene-evaluation of three disinfectant hand sanitizers in a community setting. PLoS One, 9(11), e111969.

9. Bauer et al, 1966. Antibiotic susceptibility testing by a standardized single disk method. Am J Clin Pathol. 1966;45:493-6BPOM

10. Valgas, C., Souza, S. M. D., Smânia, E. F., \& Smânia Jr, A. (2007). Screening methods to determine antibacterial activity of natural products. Brazilian journal of microbiology, 38(2), 369-380.

11. Al-Mamun, M. A., Akter, Z., Uddin, M. J., Ferdaus, K. M. K. B., Hoque, K. M. F., Ferdousi, Z., \& Reza, M. A. (2016). Characterization and evaluation of antibacterial and antiproliferative activities of crude protein extracts isolated from the seed of Ricinus communis in Bangladesh. BMC complementary and alternative medicine, 16(1), 1-10.

12. Leonardo, M. R., da Silva, L. A. B., Tanomaru Filho, M., Bonifácio, K. C., \& Ito, I. Y. (2001). In vitro evaluation of the antimicrobial activity of a castor oil-based irrigant. Journal of endodontics, 27(12), 717-719.

13. Kampf, G., Todt, D., Pfaender, S., \& Steinmann, E. (2020). Persistence of coronaviruses on inanimate surfaces and their inactivation with biocidal agents. Journal of hospital infection, 104(3), 246-251.

14. Zaidah, F. A. (2015). Uji Pembandingan Efektivitas Antiseptik Strong Acidic Water Terhadap Antiseptik Standar Etanol 70\%.

15. Rutala, W. A., \& Weber, D. J. (2008). Guideline for disinfection and sterilization in healthcare facilities, 2008.

16. Greenwood, 2000. Detection of antibiotic resistance in vitro. International Journal of Antimicrobial Agents 14(4):303-6

17. Tuladhar, E., Hazeleger, W. C., Koopmans, M., Zwietering, M. H., Duizer, E., \& Beumer, R. R. (2015). Reducing viral contamination from finger pads: handwashing is more effective than alcohol- based hand disinfectants. Journal of Hospital Infection, 90(3), 226-234. 